\section{Forum: equity in access to health care. Postscript}

\author{
Fórum: eqüidade no acesso aos serviços de saúde. \\ Posfácio
}

${ }^{1}$ Escola Nacional de Saúde Pública Sergio Arouca, Fundação Oswaldo Cruz, Rio de Janeiro, Brasil.

Correspondence C. Almeida Departamento de Administração e Planejamento em Saúde, Escola Nacional de Saúde Pública Sergio Arouca, Fundação Oswaldo Cruz. Rua Leopoldo Bulhões 1480, Rio de Janeiro, $R J$ 21041-210, Brasil. calmeida@ensp.fiocruz.br
The papers published in this Forum have one feature in common. The issue they discuss, health services access and equity, is relatively well covered in the specialized literature, although far from reaching a consensus. However, the papers shed light on specific new aspects that are key for understanding the problem in greater depth and finding solutions with improved outcomes. These aspects have received limited attention in the literature and require further investigation.

Mooney \& Houston argue that the issue of trust in the context of health care, and more specifically the "lack of institutional trust as a major barrier to more equal access to health care, especially where this is accompanied by generalized distrust" (p. 1163). They base their discussion on the situation of Australian aborigines, adding quite rightly that their thinking could be applied to the same problem facing indigenous peoples in Latin America. In my view, the credibility of state institutions (and by association the state itself) is questioned far more widely in our countries today - in society as a whole and not only among the most marginalized groups - with dramatic repercussions on health institutions and services.

The examples are abundant. Right here in Brazil, people's disbelief in "official discourse", and by extension in the orientation from public health authorities, also discredits the National Unified Health System (SUS) and not only aggravates barriers to access, but jeopardizes the
Celia Almeida 1

use of available services. In a recent example, the Ministry of Health stepped up yellow fever vaccination in response to an increase in cases and deaths among individuals with wild yellow fever who had visited forest regions where the disease is endemic. This increase in cases was consistent with the epidemiological cycle of the disease, which was investigated and proven not to be a resurgence of urban yellow fever (eradicated from Brazil in the 1940s). Consequently, it was recommended that only people planning to travel to risk areas (which are well known and publicized by the Ministry of Health itself) receive the vaccine. Even so, people flocked in panic to health centers in practically all the major cities, rapidly exhausting available supplies of the vaccine and hindering vaccination of those planning to travel to endemic areas and who actually required immunization. Numerous individuals were vaccinated more than once unnecessarily in a short space of time, with serious consequences, although it was announced repeatedly that the vaccine itself is not completely harmless or risk-free, and that it provides immunization for 10 years!

A similar situation has arisen in various basic health programs, an official Brazilian health policy priority: the Family Health Program, the Community Health Agents Program, and the Program to Combat Aedes aegypti (the mosquito vector for dengue fever, which has been endemic and epidemic for over a decade in Rio 
de Janeiro and other cities). Various problems have arisen with these programs. The first two have still not taken off in Brazil's main urban areas because they fail to engage the middle and upper classes. The latter is unable to make effective headway against mosquito infestation, particularly in Rio de Janeiro, largely because: 1) urban violence blocks access by health agents to inspect and eliminate possible mosquito breeding sites in areas controlled by the drug traffic and organized crime and 2) many people in the wealthier social groups refuse to allow health agents into their homes, purportedly out of fear and insecurity (robbers could "pose" as health agents!), but mainly because they believe that such public health measures are unnecessary for them ("dengue is a problem for the poor") and they resist taking the necessary measures in their own homes to prevent mosquito larva infestation. Year after year, dengue kills more and more people in Rio de Janeiro, in all socioeconomic classes, but meting out heavier punishment on the poor. As Mooney \& Houston point out, individualism is running rampant, while the "community spirit" that stimulates and sustains solidarity is being lost!

These two situations, briefly described, lead us to the study by Thiede \& McIntyre, where access is defined as the freedom to use, building on the notion of empowerment and regarding information as the essential prerequisite for access. The Brazilian people have grounds for mistrusting the state, for a number of reasons that are beyond the scope of this Postscript. However, there is also a great deal of misinformation and great difficulty in transmitting important, correct information to individuals in society, although it is often announced exhaustively by government agencies and broadcast (however dubiously) by the media. A number of hypotheses are being examined, foremost of which is the role of the media - particularly print and radio - in this process.

A striking fact about the print media is that relatively few Brazilians read newspapers. In a country with a population of 180 million, mainly concentrated in urban areas, approximately 7 million read newspapers 1 . I am not talking about the many who fail to read either because they are illiterate or cannot afford to buy a newspaper. Rather, I refer to the social groups who can indeed afford newspapers and have the power to formulate opinions, and who thus bear greater responsibility.

At most, people read the headlines splashed across the front pages, on display at the corner newsstand. As if that were not enough, Brazil's mainstream press is alarmist and sensational- ist, spreading panic rather than balanced enlightenment. Headlines often fail to reflect the central content of the article inside the paper, which in other cases is often also manipulated. This situation is reproduced to some extent, with rare exceptions, by the mainstream radio and television channels, which reach far larger audiences.

This issue is obviously beyond the scope of our modest debate here and relates to the much broader problem of communication in Brazil (which is regulated by old legislation, dating to 1962 , completely outdated in light of current technological progress and the ongoing Brazilian reality 2,3) and the power differentials among actors in society. However, it is also evident that the state in general and the health sector in particular need to reformulate the way they communicate with society. Thus, one of the most important issues in debate today in Brazil, and not only in the health sector, is exactly how to do this: with what instruments, and on the basis of what strategic policies?

As Thiede \& McIntyre warn: "the characteristics of information that impact the health system's clients'subjective choice sets and the mechanism in whichinformation istransferredbetween theactors in the health system (...) the degree to which health information becomes effective and empowers people to exercise their choice with respect to the opportunity to utilize health services..." (pp. 1170-1). The communicative interaction between the dynamics of socioeconomics and socio-cultural background "needs to address aspects of life further than the medical system" (p. 1171).

Lastly, the poignant life experiences described by Castro reiterate the issues discussed above.

Health systems are social constructs and as such can certainly be an arena of confrontation among the power differentials underlying health inequalities, helping to reduce them and mitigate their adverse effects on people's health 4 . In recent decades, however, rampant individualism, war, political excesses of every order, deteriorating health and living conditions among vast portions of the world's population, lack of investment in social policies, and disastrous "pro-market" reforms 5 implemented in health, among other sectors, particularly in the world's South, have destroyed the structure of centuries-old beliefs and left entire populations defenseless.

Within this "scorched earth", how can the idea of access to health as a fundamental right be rebuilt on the basis of restored acceptable ethical and moral values? This challenge requires first achieving individual and social wellbeing on the basis of a (re)emergence of the col- 
lective (or communitarianism?), of the public domain as the main partner in dialogue with the agents (actors) who produce social goods and the citizens (or users) who utilize them. It is therefore a shared struggle where all have to play their part.
This appears to be the great ethical and political challenge of the new millennium. Our distinguished guests at this Forum have given us their invaluable contributions.

Thank you!

\section{References}

1. Egypto L. Nada a comemorar. http://www. observatoriodaimprensa.com.br/blogs.asp?id blog $=8 \&$ dia $=30 \&$ mes $=1 \&$ ano $=2008$ (accessed on 23/Feb/2008).

2. Silva JDO. Regulação não é censura. http://www. zedirceu.com.br/index.php?option=com_content \&task=view\&id=626\&Itemid=63 (accessed on 29/ Mar/2008).

3. Miguel LF. Meios de comunicação de massa e política no Brasil. Diálogos Latinoamericanos, 003. http://redalyc.uaemex. $\mathrm{mx} /$ redalyc/ pdf/162/16200302.pdf (accessed on 29/ $\mathrm{Mar} / 2008)$.
4. Gilson L, Doherty J, Loewenson R, Francis V. Challenging inequity through health systems. Final report: knowledge network on health systems. http://www.who.int/social_determinants / resources/csdh_media/hskn_final_2007_en.pdf (accessed on 22/Feb/2008).

5. United Nations Research Institute for Social Development. Conference news. Equitable access to health care and infectious disease control: concepts, measurement and interventions. http:// www.who.int/tdr/publications/publications / conference_news.htm (accessed on 20/Feb/2008).

Submitted on 06/Mar/2008

Approved on 19//Mar/2008 